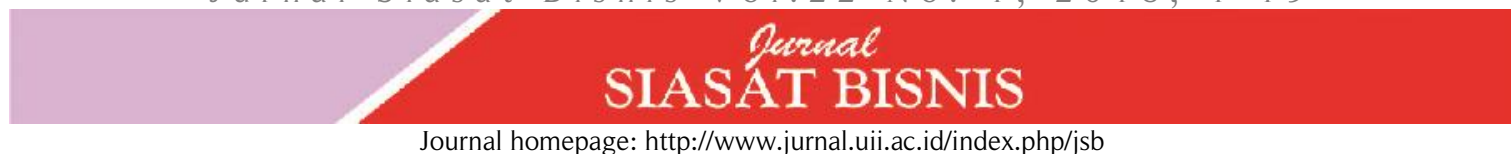

\title{
Perkembangan penelitian di bidang pengungkapan di Indonesia: Telaah konseptual
}

\author{
Aqlima Cendera Dewi ${ }^{*}$, Aning Fitriana, Doddy Setiawan ${ }^{1}$ \\ Fakultas Ekonomi dan Bisnis, Universitas Sebelas Maret \\ Jl. Ir Sutami No. 36-A Kentingan, Surakarta, 57126, Indonesia \\ *Corresponding author: dewicendera61@gmail.com \\ Received: 25-12-2017, Accepted: 20-02-2018, Published: 16-03-2018
}

\begin{abstract}
This study aims to provide an overview of the development of corporate information disclosure research in Indonesia taken from 11 accredited journals in Indonesia. Samples are obtained from 2004 to 2017 and obtained 66 articles covering the practice of corporate information disclosure. This research classifies articles based on topics, research methods and models used by researchers. The widest researched topics of corporate information disclosure practices are the antecedent topics of firm size and financial ratios, while the widest used research methods are analytical methods. In addition, the corporate social responsibility-based disclosure is widely studied since this disclosure was probably considered as concern of many parties, especially the general public, and causing conflict in the community.
\end{abstract}

Keywords: analytical method, bibliography, corporate social responsibility disclosure, disclosure, literature review

\begin{abstract}
Abstrak
Penelitian ini bertujuan untuk memberikan gambaran perkembangan penelitian pengungkapan informasi perusahaan di Indonesia yang diambil dari 11 jurnal terakreditasi di Indonesia. Sampel diperoleh dari tahun 2004 sampai dengan 2017 dan diperoleh sebanyak 66 artikel yang membahas mengenai praktik pengungkapan informasi perusahaan. penelitian ini mengklasifikasikan artikel berdasarkan topik, metode penelitian dan model yang digunakan oleh peneliti. Topik yang paling banyak diteliti dari praktik pengungkapan informasi perusahaan adalah topik anteseden yaitu ukuran perusahaan dan rasio keuangan, sedangkan metode penelitian yang paling banyak digunakan adalah metode analitik. Sementara pengungkapan berbasis corporate social responsibility adalah yang paling banyak diteliti karena kemungkinan dianggap menyangkut banyak pihak terutama masyarakat umum dan banyak menimbulkan konflik ditengah masyarakat.
\end{abstract}

Kata Kunci: bibliografi, metode analitik, pengungkapan informasi perusahaan, pengungkapan corporate social responsibility, telaah literatur

JEL: G34, M1, M14, Q56

DOI: $10.20885 /$ jsb.vol22.iss1.art1

\section{Pendahuluan}

Konflik kepentingan diantara para pemangku kepentingan (stakeholders) yang disebabkan oleh asimetri informasi menimbulkan penipuan serta penyalahgunaan yang menyebabkan kerugian bagi perusahaan, seperti pada kasus Enron, WorldCom, dan Parmalat. Oleh karena itu, pengungkapan informasi perusahaan sangat penting dilakukan untuk mengurangi asimetri informasi guna menekan konflik kepentingan yang muncul akibat adanya pemisahan kepemilikan dengan pengelolaan. Hal tersebut menyebabkan banyak peneliti tertarik untuk melakukan penelitian lebih dalam mengenai praktik pelaporan keuangan perusahaan publik di dunia. Tidak hanya di dunia, di Indonesia hal tersebut juga memotivasi para peneliti untuk mengevaluasi praktik pengungkapan informasi perusahaan publik di Indonesia. 
Penelitian mengenai pengungkapan informasi perusahaan telah banyak dilakukan baik di Indonesia, misalnya oleh Faizal dan Probohudono (2013), Supriyono dan Suhardjanto (2013) dan Suhardjanto dan Wardhani (2010), maupun di Luar Negeri, seperti oleh Belkaoui dan Karpik (1989), Ho dan Wong (2001), Eng dan Mak (2003), Yuen, Liu, Zhang dan Lu (2009) dan Akhtaruddin, Hossain, Hossain dan Yao (2009). Dari berbagai penelitian, hasilnya sangat beragam dan menarik untuk diteliti kembali baik dari anteseden maupun konsekuensi dari praktik pengungkapan informasi perusahaan. Mulai berkembangnya jurnal-jurnal akuntansi dan manajemen bisnis di Indonesia yang mencoba untuk mendokumentasikan serta mengevaluasi hasil penelitian tersebut telah memotivasi peneliti untuk meneliti lebih lanjut bagaimana perkembangan penelitian mengenai praktik pengungkapan informasi keuangan di Indonesia dalam bentuk bibliografi.

Penelitian ini termotivasi dari penelitian yang dilakukan oleh Hesford, Lee, Van der Stede dan Young (2007) mengenai penelitian bibliografi di bidang akuntansi manajemen. Peneliti mencoba untuk mengkaji mengenai praktik pengungkapan laporan keuangan di Indonesia dengan metode yang sama dengan menggunakan hasil penelitian dari 66 artikel tentang pengungkapan laporan keuangan di 11 jurnal terakreditasi di bidang akuntansi dan keuangan, manajemen, auditing, perpajakan dan ekonomi di Indonesia selama periode 14 tahun (dari tahun 2004 sampai dengan 2017). Kami memilih jurnal yang terakreditasi sebagai bahan pengamatan karena jurnal terakreditasi telah melalui seleksi yang ketat sehingga artikel yang diterbitkan memiliki kredibilitas dan kualitas yang baik. Penelitian ini menggunakan dua pendekatan yaitu "charting the field" dan "analyzing the community" untuk menganalisis dan memetakan perkembangan penelitian mengenai praktik pengungkapan informasi perusahaan selama 14 tahun terakhir dari beberapa jurnal terakreditasi di Indonesia dari berbagai aspek.

Kontribusi dari penelitian ini adalah pertama, mengklasifikasikan topik penelitian mengenai pengungkapan informasi perusahaan berdasarkan anteseden, konsekuensi, metode penelitian, populasi dan model pengungkapan. Kedua, artikel ini memberikan gambaran kepada peneliti selanjutnya untuk mengevaluasi dan menganalisis lebih lanjut beberapa variabel, topik atau metode penelitian yang masih jarang dilakukan di Indonesia yang berkaitan dengan praktik pengungkapan informasi perusahaan.

\section{Metode}

Metode yang digunakan dalam penelitian ini adalah metode "charting the field" yang dikembangkan oleh Hesford et al. (2007). Dalam pendekatan ini, peneliti memilih beberapa hasil penelitian mengenai praktik pengungkapan informasi perusahaan atau yang sejenisnya yang diterbitkan di 11 jurnal terakreditasi, kemudian dikelompokkan berdasarkan topik, metode penelitian dan disiplin ilmu. Nama jurnal yang menjadi sampel penelitian dapat dilihat di tabel 1 . Pemilihan jurnal-jurnal diatas sesuai dengan kriteria: pertama, jurnal terakreditasi pada tahun 2017. Kedua, jurnal dapat diakses secara online. Peneliti memilih secara terstruktur dan sistematis seluruh artikel yang diterbitkan di setiap jurnal tersebut. Ketiga, hanya memilih artikel yang terkait dengan pengungkapan informasi perusahaan di Indonesia.

Tahap pemilihan sampel: Pertama, peneliti mencari data mengenai jurnal apa saja yang terakreditasi atau memiliki izin ISSN oleh DIKTI dilaman DIKTI yang berjumlah 30 jurnal. Kedua, peneliti membuka satu persatu portal jurnal terakreditasi. Ketiga, disetiap jurnal peneliti mengetik kata "pengungkapan" atau "disclosure" pada kolom research. Pada tahap ketiga ini setelah kami memasukkan keyword jika tidak kami temukan artikel terkait maka kami keluarkan dari populasi yang awalnya berjumlah 30 jurnal menjadi 11 jurnal. Keempat, peneliti mendownload setiap artikel yang ada di jurnal tersebut. Kelima, mengklasifikasikan artikel dalam sebuah tabulasi data berdasarkan judul, variabel, populasi dan sampel, hasil serta nama penulis dan tahun terbit. 
Tabel 1. Daftar Nama Jurnal

\begin{tabular}{cllc}
\hline No & Nama Jurnal & Institusi & $\begin{array}{c}\text { Jumlah } \\
\text { Artikel }\end{array}$ \\
\hline 1 & Jurnal Akuntansi Multiparadigma (JAMAL) & Universitas Brawijaya & 11 \\
2 & Jurnal Aplikasi Manajemen (JAM) & Universitas Brawijaya & 4 \\
3 & Jurnal Akuntansi dan Auditing Indonesia (JAAI) & Universitas Islam Indonesia & 10 \\
4 & Jurnal Akuntansi dan Keuangan Indonesia (JAKI) & Universitas Indonesia & 18 \\
5 & Jurnal Siasat Bisnis (JSB) & Universitas Islam Indonesia & 3 \\
6 & Jurnal Akuntansi dan Keuangan (JAK) & Universitas Petra & 7 \\
7 & Jurnal Keuangan dan Perbankan (JKP) & Universitas Merdeka Malang & 5 \\
8 & Jurnal Dinamika Manajemen (JDM) & Universitas Negeri Semarang & 3 \\
9 & Jurnal Manajemen Bisnis (JMB) & Prasetyo Mulya Business School Jakarta & 1 \\
10 & International Journal Research of Business Studies & Prasetyo Mulya Business School Jakarta & 1 \\
11 & GaRBS) & Universitas Gadjah Mada & 3 \\
\hline
\end{tabular}

\section{Hasil}

Penelitian ini menggunakan 66 artikel yang diperoleh dari 11 jurnal terakreditasi nasional yang telah memenuhi kriteria. Adapun nama jurnal, judul artikel dan nama peneliti disajikan pada Tabel 2.

Tabel 2. Daftar Artikel Sampel

\begin{tabular}{|c|c|c|c|c|}
\hline No & $\begin{array}{l}\text { Nama } \\
\text { Jurnal }\end{array}$ & Judul & Nama Peneliti & $\begin{array}{l}\text { Jumlah } \\
\text { sitasi }\end{array}$ \\
\hline 1 & JAMAL & $\begin{array}{l}\text { Pengungkapan Pro Forma dan Keputusan Investor: Uji } \\
\text { Empiris Teori Signal dan Teori Pasar Efisien di Bursa Efek } \\
\text { Indonesia (BEI) }\end{array}$ & $\begin{array}{l}\text { Rura, Subroto dan Rosidi } \\
\text { (2011) }\end{array}$ & 3 \\
\hline 2 & JAMAL & $\begin{array}{l}\text { The Concept of Social Responsibility Disclosures For Islamic } \\
\text { Banks Based on Shari'ah Enterprise Theory }\end{array}$ & Meutia (2010) & 1 \\
\hline 3 & JAMAL & $\begin{array}{l}\text { Pengungkapan Pro Forma, Mendukung atau Menyesatkan } \\
\text { Investor? }\end{array}$ & Rura (2010) & 0 \\
\hline 4 & JAMAL & $\begin{array}{l}\text { Penerapan PSAK No.109 atas Pengungkapan Wajib dan } \\
\text { Sukarela }\end{array}$ & $\begin{array}{l}\text { Puspitasari dan } \\
\text { Habiburrochman (2013) }\end{array}$ & 0 \\
\hline 5 & JAMAL & $\begin{array}{l}\text { Karakteristik Perusahaan, Luas Pengungkapan Corporate } \\
\text { Social Responsibility dan Nilai Perusahaan }\end{array}$ & $\begin{array}{l}\text { Ibrahim, Solikahan dan } \\
\text { Widyatama (2015) }\end{array}$ & 0 \\
\hline 6 & JAMAL & $\begin{array}{l}\text { Konstruksi Model Pengukuran Kinerja dan Kerangka Kerja } \\
\text { Pengungkapan Modal Intelektual }\end{array}$ & $\begin{array}{l}\text { Ulum, Ghozali danAgus } \\
\text { (2014) }\end{array}$ & 5 \\
\hline 7 & JAMAL & $\begin{array}{l}\text { Memaknai Disclosure Laporan Sumber dan Penggunaan Dana } \\
\text { Kebajikan (Qardhul Hasan) Bank Syariah }\end{array}$ & Ali (2012) & 3 \\
\hline 8 & JAMAL & $\begin{array}{l}\text { Luas Pengungkapan dan Dampak terhadap Asimetri Informasi } \\
\text { Perusahaan Sektor Keuangan }\end{array}$ & $\begin{array}{l}\text { Kurnianto, Sutrisno dan } \\
\text { Saraswati (2014) }\end{array}$ & 0 \\
\hline 9 & JAMAL & $\begin{array}{l}\text { Pengaruh Tingkat Pengungkapan Wajib dan Pengungkapan } \\
\text { Sukarela terhadap Biaya Modal Ekuitas }\end{array}$ & $\begin{array}{l}\text { Wulandari dan Atmini } \\
\text { (2012) }\end{array}$ & 2 \\
\hline 10 & JAMAL & $\begin{array}{l}\text { Penerapan Internet Financial Reporting untuk Meningkatkan } \\
\text { Akuntabilitas Organisasi Pengelola Zakat }\end{array}$ & Rini (2016) & 0 \\
\hline 11 & JAMAL & $\begin{array}{l}\text { Corporate Social Responsibility: Implikasi Stakeholder dan } \\
\text { Legitimacy Gap dalam Peningkatan Kinerja Perusahaan }\end{array}$ & $\begin{array}{l}\text { Lindawati dan Puspita } \\
\text { (2015) }\end{array}$ & 5 \\
\hline 12 & JAAI & $\begin{array}{l}\text { The Occurrence of Environmental Disclosures in The Annual } \\
\text { Reports }\end{array}$ & Susi (2009) & 0 \\
\hline 13 & JAAI & $\begin{array}{l}\text { Persepsi Penyedia dan Pemakai Laporan Keuangan terhadap } \\
\text { Pengungkapan Biaya Riset dan Pengembangan }\end{array}$ & Sayidah (2004) & 3 \\
\hline 14 & JAAI & $\begin{array}{l}\text { Islamic Corporate Social Responsibility Disclosure, Reputasi, } \\
\text { dan Kinerja Keuangan: Studi pada Bank Syariah di Indonesia }\end{array}$ & $\begin{array}{l}\text { Arifin dan Wardani } \\
(2016)\end{array}$ & 2 \\
\hline 15 & JAAI & Intellectual Capital Disclosure: Suatu Analisis dengan Four & Ulum (2015) & 1 \\
\hline
\end{tabular}




\begin{tabular}{|c|c|c|c|c|}
\hline No & $\begin{array}{l}\text { Nama } \\
\text { Jurnal }\end{array}$ & Judul & Nama Peneliti & $\begin{array}{c}\text { Jumlah } \\
\text { sitasi }\end{array}$ \\
\hline 16 & JAAI & $\begin{array}{l}\text { Way Numerical Coding System } \\
\text { Voluntary Disclosure In Indonesia: Comparison Of Shariah } \\
\text { And Non Shariah Compliant Companies }\end{array}$ & Nugraheni (2011) & 1 \\
\hline 17 & JAAI & $\begin{array}{l}\text { Praktik Intellectual Capital Disclosure Perusahaan yang } \\
\text { Terdaftar di Bursa Efek Indonesia }\end{array}$ & $\begin{array}{l}\text { Suhardjanto dan Miranti } \\
\text { (2010) }\end{array}$ & 50 \\
\hline 18 & JAAI & $\begin{array}{l}\text { The Analysis of Company Characteristic Influence Toward } \\
\text { CSR Disclosure: Empirical Evidence of Manufacturing } \\
\text { Companies Listed In JSX }\end{array}$ & $\begin{array}{l}\text { Rahman dan widyasari } \\
(2008)\end{array}$ & 36 \\
\hline 19 & JAAI & $\begin{array}{l}\text { Pengaruh Kualitas Pengungkapan Informasi terhadap } \\
\text { Hubungan antara Penerapan Corporate Governance dengan } \\
\text { Kinerja Perusahaan di Bursa Efek Jakarta }\end{array}$ & Hidayah (2008) & 51 \\
\hline 20 & JAAI & $\begin{array}{l}\text { Intellectual Capital dan Intellectual Capital } \\
\text { Disclosureterhadap MarketPerformancepada Perusahaan } \\
\text { Publik Indeks LQ-45 }\end{array}$ & $\begin{array}{l}\text { Shella dan Wedari } \\
(2016)\end{array}$ & 0 \\
\hline 21 & JAAI & $\begin{array}{l}\text { Determinan Voluntary Nonfinancial Disclosure pada } \\
\text { Perusahaan di Indonesia }\end{array}$ & $\begin{array}{l}\text { Faizal dan Probohudono } \\
\text { (2013) }\end{array}$ & 0 \\
\hline 22 & JDM & $\begin{array}{l}\text { Analisis Company Size, Financial Leverage dan Profitabilitas } \\
\text { serta Pengaruhnya terhadap Pengungkapan CSR }\end{array}$ & $\begin{array}{l}\text { Riantani dan Nurzamzam } \\
\text { (2015) }\end{array}$ & 0 \\
\hline 23 & JDM & $\begin{array}{l}\text { Pengaruh Pengungkapan Corporate Social } \\
\text { Responsibilityterhadap Earning Response Coefficient }\end{array}$ & $\begin{array}{l}\text { Restuti dan Nathaniel } \\
(2012)\end{array}$ & 18 \\
\hline 24 & JDM & Arranging The Index of Corporate Governance & Surifah (2011) & 0 \\
\hline 25 & JSB & $\begin{array}{l}\text { Pengaruh Mekanisme Corporate Governance dan } \\
\text { Karakteristik Perusahaan terhadap Pengungkapan } \\
\text { Tanggungjawab Sosial }\end{array}$ & $\begin{array}{l}\text { Cahyaningsih dan } \\
\text { Martina (2011) }\end{array}$ & 0 \\
\hline 26 & JSB & $\begin{array}{l}\text { The Impact of Type of Industry, Company Size and Leverage } \\
\text { on The Disclosure of Corporate Social Responsibility }\end{array}$ & Widyadmono (2014) & 0 \\
\hline 27 & JSB & $\begin{array}{l}\text { Praktik Pengungkapan Sosial: Studi Komparatif di Asia } \\
\text { Tenggara }\end{array}$ & $\begin{array}{l}\text { Supriyono dan } \\
\text { Suhardjanto (2013) }\end{array}$ & 1 \\
\hline 28 & JAK & $\begin{array}{l}\text { Pengaruh Pengungkapan Corporate Social Responsibility } \\
\text { (CSR) terhadap Earning Response Coefficient (ERC) (Suatu } \\
\text { Studi Empiris pada Perusahaan Pertambangan yang terdaftar } \\
\text { di Bursa Efek Indonesia pada Tahun 2010-2013) }\end{array}$ & $\begin{array}{l}\text { Awuy, Sayekti dan } \\
\text { Purnamawati (2016) }\end{array}$ & 0 \\
\hline 29 & JAK & $\begin{array}{l}\text { Carbon Emission Disclosure: Studi pada Perusahaan } \\
\text { Manufaktur di Indonesia }\end{array}$ & $\begin{array}{l}\text { Irwhantoko dan Basuki } \\
\text { (2016) }\end{array}$ & 0 \\
\hline 30 & JAK & Pengungkapan Sustainability Report dan Kinerja Keuangan & $\begin{array}{l}\text { Tarigan dan Semuel } \\
\text { (2014) }\end{array}$ & 13 \\
\hline 31 & JAK & $\begin{array}{l}\text { Faktor-Faktor yang Mempengaruhi Luas Pengungkapan } \\
\text { Sukarela }\end{array}$ & Wardani (2012) & 26 \\
\hline 32 & JAK & $\begin{array}{l}\text { Hubungan Tingkat Pengungkapan dan Kinerja Corporate } \\
\text { Social Responsibility Serta Manajemen Laba: Pengujian Teori } \\
\text { Ekonomi dan Sosio Politis }\end{array}$ & $\begin{array}{l}\text { Ratmono, Purwanto dan } \\
\text { Cahyonowati (2014) }\end{array}$ & 1 \\
\hline 33 & JAK & $\begin{array}{l}\text { Pengaruh Good Corporate Governance, Voluntary Disclosure } \\
\text { terhadap Biaya Hutang }\end{array}$ & $\begin{array}{l}\text { Juniarti dan Sentosa } \\
\text { (2009) }\end{array}$ & 9 \\
\hline 34 & JAK & $\begin{array}{l}\text { Pengaruh Modal Intelektual Kapital dan Pegungkapannya } \\
\text { terhadap Kinerja Perusahaan }\end{array}$ & Santoso (2012) & 19 \\
\hline 35 & JKP & $\begin{array}{l}\text { Dewan Komisaris dan Intellectual Capital Disclosure pada } \\
\text { Perbankan di Indonesia }\end{array}$ & Uzliawati (2014) & 1 \\
\hline 36 & JKP & $\begin{array}{l}\text { Kepemilikan Institusional dan Kualitas Audit terhadap } \\
\text { Pengungkapan Informasi dan Future Earnings Response } \\
\text { Coefficient }\end{array}$ & Murwaningsari (2014) & 1 \\
\hline 37 & JKP & Pengungkapan Tanggungjawab Sosial Perbankan di Indonesia & Nussy (2014) & 1 \\
\hline 38 & JKP & $\begin{array}{l}\text { Perbandingan Tingkat dan Ruang Pengungkapan Pelaporan } \\
\text { Keuangan Basis Internat terhadap Harga Saham }\end{array}$ & $\begin{array}{l}\text { Nur DP dan Susilowati } \\
\text { (2015) }\end{array}$ & 0 \\
\hline 39 & JKP & Analisis Pengungkapan Tata Kelola Bank Syariah di Indonesia & $\begin{array}{l}\text { Adiono dan Sholihin } \\
\text { (2014) }\end{array}$ & 2 \\
\hline 40 & GMIJB & Voluntary Disclosure in the Annual Reports of Financially & Wijantini (2006) & 3 \\
\hline
\end{tabular}

4 (ㅇ 2018 The Authors. Jurnal Siasat Bisnis. Published by The Management Development Centre, Department of Management, Faculty of Economics, Universitas Islam Indonesia 


\begin{tabular}{|c|c|c|c|c|}
\hline No & $\begin{array}{l}\text { Nama } \\
\text { Jurnal }\end{array}$ & Judul & Nama Peneliti & $\begin{array}{c}\text { Jumlah } \\
\text { sitasi }\end{array}$ \\
\hline 41 & GMIJB & $\begin{array}{l}\text { Distressed Companies in Indonesia } \\
\text { A Longitudinal Examination of Environmental Reporting } \\
\text { Practices In Malaysia }\end{array}$ & $\begin{array}{l}\text { Alrazi, Sulaiman dan } \\
\text { Ahmad (2009) }\end{array}$ & 28 \\
\hline 42 & GMIJB & $\begin{array}{l}\text { The Impact of Financial, Non-Financial, and Corporate } \\
\text { Governance Attributes onThe Practice of Global Reporting } \\
\text { Initiative (GRI)Based Environmental Disclosure }\end{array}$ & $\begin{array}{l}\text { Frendy dan Kusuma } \\
\text { (2011) }\end{array}$ & 2 \\
\hline 43 & JAKI & $\begin{array}{l}\text { Penentuan Besaran Transaksi Pihak Berelasi: Tata Kelola, } \\
\text { Tingkat Pengungkapan dan Struktur Kepemilikan }\end{array}$ & Utama (2015) & 5 \\
\hline 44 & JAKI & $\begin{array}{l}\text { Analisis Pengungkapan Laporan Keuangan Perusahaan } \\
\text { Pembiayaan }\end{array}$ & $\begin{array}{l}\text { Oktaviani dan Martani } \\
\text { (2006) }\end{array}$ & 4 \\
\hline 45 & JAKI & $\begin{array}{l}\text { Pengaruh Karakteristik Perusahaan terhadap Pengungkapan } \\
\text { Corporate Social Responsibility dan Dampaknya terhadap } \\
\text { Reaksi Investor }\end{array}$ & $\begin{array}{l}\text { Yuliana, Purnomosidhi } \\
\text { dan Sukoharsono (2008) }\end{array}$ & 28 \\
\hline 46 & JAKI & $\begin{array}{l}\text { Simbolis atau Substantif? Analisis Praktik Pelaporan CSR dan } \\
\text { Kualitas Pengungkapan }\end{array}$ & $\begin{array}{l}\text { Nasution dan Adhariani } \\
\text { (2016) }\end{array}$ & 0 \\
\hline 47 & JAKI & $\begin{array}{l}\text { Pengaruh Modal Intelektual dan Pengungkapan Modal } \\
\text { Intelektual pada Nilai Perusahaan yang Melakukan Initial } \\
\text { Public Offering }\end{array}$ & Widarjo (2011) & 25 \\
\hline 48 & JAKI & $\begin{array}{l}\text { Tingkat Keluasan Pengungkapan Sukarela dalam Laporan } \\
\text { Tahunan dan Hubungannya dengan Current Earnings } \\
\text { Response Coefficient }\end{array}$ & Adhariani (2005) & 12 \\
\hline 49 & JAKI & $\begin{array}{l}\text { Pengungkapan Non Financial Measures: Penilaian Value } \\
\text { Relevance bagi Investor dan Pengaruhnya terhadap Cost of } \\
\text { Equity dan Performance bagi Perusahaan Publik }\end{array}$ & Wondabio (2007) & 1 \\
\hline 50 & JAKI & $\begin{array}{l}\text { Pengaruh Liputan Media, Kepekaan Industri, dan Struktur } \\
\text { Tata Kelola Perusahaanterhadap Kualitas Pengungkapan } \\
\text { Lingkungan }\end{array}$ & $\begin{array}{l}\text { Solikahan dan Winarsih } \\
\text { (2015) }\end{array}$ & 0 \\
\hline 51 & JAKI & $\begin{array}{l}\text { Slack Resources, Feminisme Dewan, dan Kualitas } \\
\text { Pengungkapan Tanggung Jawab Sosial Perusahaan }\end{array}$ & $\begin{array}{l}\text { Anggraeni dan Djakman } \\
\text { (2017) }\end{array}$ & 0 \\
\hline 52 & JAKI & $\begin{array}{l}\text { Dampak Tingkat Pengungkapan Informasi Perusahaan } \\
\text { Terhadap Volume Perdagangan dan Return Saham (Penelitian } \\
\text { Empiris Terhadap Perusahaan-Perusahaan yang tercatat di } \\
\text { Bursa Efek Jakarta) }\end{array}$ & Junaedi (2005) & 44 \\
\hline 53 & JAKI & $\begin{array}{l}\text { Electronic Disclosure pada Perusahaan Telekomunikasi Asia } \\
\text { Pasifik di New York Stock Exchange }\end{array}$ & Kesumajuda (2006) & 0 \\
\hline 54 & JAKI & $\begin{array}{l}\text { Pengungkapan Emisi Gas Rumah Kaca, Kinerja Lingkungan } \\
\text { dan Nilai }\end{array}$ & Anggraeni (2015) & 0 \\
\hline 55 & JAKI & $\begin{array}{l}\text { Determinan Pengungkapan Informasi Atribusi dan } \\
\text { Dampaknya terhadap Persistensi Laba }\end{array}$ & Suripto (2014) & 0 \\
\hline 56 & JAKI & $\begin{array}{l}\text { Pengaruh Pengungkapan Enterprise Risk Management dan } \\
\text { Pengungkapan Intellectual Capital terhadap Nilai Perusahaan }\end{array}$ & $\begin{array}{l}\text { Devi dan Budiasih (2017) } \\
\text { Badera (2017) }\end{array}$ & 0 \\
\hline 57 & JAKI & $\begin{array}{l}\text { Pengaruh Mekanisme Corporate Governance terhadap } \\
\text { Pengungkapan Intellectual Capital: pada Perusahaan IC } \\
\text { Intensive }\end{array}$ & Arifah (2012) & 5 \\
\hline 58 & JAKI & $\begin{array}{l}\text { Pengaruh Struktur Corporate Governance dan Kualitas Audit } \\
\text { terhadap Luas Pengungkapan Kompensasi Manajemen Kunci } \\
\text { di Laporan Keuangan }\end{array}$ & Akmyga dan Mita (2015) & 1 \\
\hline 59 & JAKI & $\begin{array}{l}\text { Tingkat Pengungkapan dan Penggunaan Derivatif Keuangan } \\
\text { dalam Aktivitas Penghindaran Pajak }\end{array}$ & $\begin{array}{l}\text { Oktavia dan Martani } \\
\text { (2013) }\end{array}$ & 3 \\
\hline 60 & JAKI & $\begin{array}{l}\text { Pengaruh Konsentrasi Kepemilikan, Ukuran Perusahaan dan } \\
\text { Mekanisme Corporate Governance terhadap Pengungkapan } \\
\text { Sukarela }\end{array}$ & Nuryaman (2009) & 2 \\
\hline 61 & IRJBS & $\begin{array}{l}\text { Corporate Social Responsibility Disclosure, Environmental } \\
\text { Performance, and Tax Aggressiveness }\end{array}$ & Sari dan Tjen (2016) & 0 \\
\hline 62 & JMB & $\begin{array}{l}\text { Perataan Laba terhadap Reaksi Pasar dengan Mekanisme } \\
\text { Good Corporate Governance dan CSRDisclosure }\end{array}$ & Restuningdiah (2011) & 14 \\
\hline 63 & JAM & $\begin{array}{l}\text { Pengaruh Kepemilikan Institusional, Komposisi Dewan } \\
\text { Komisaris, Kinerja Perusahaan terhadap Luas Pengungkapan }\end{array}$ & $\begin{array}{l}\text { Sari, Sutrisno dan } \\
\text { Sukoharsono (2013) }\end{array}$ & 2 \\
\hline
\end{tabular}




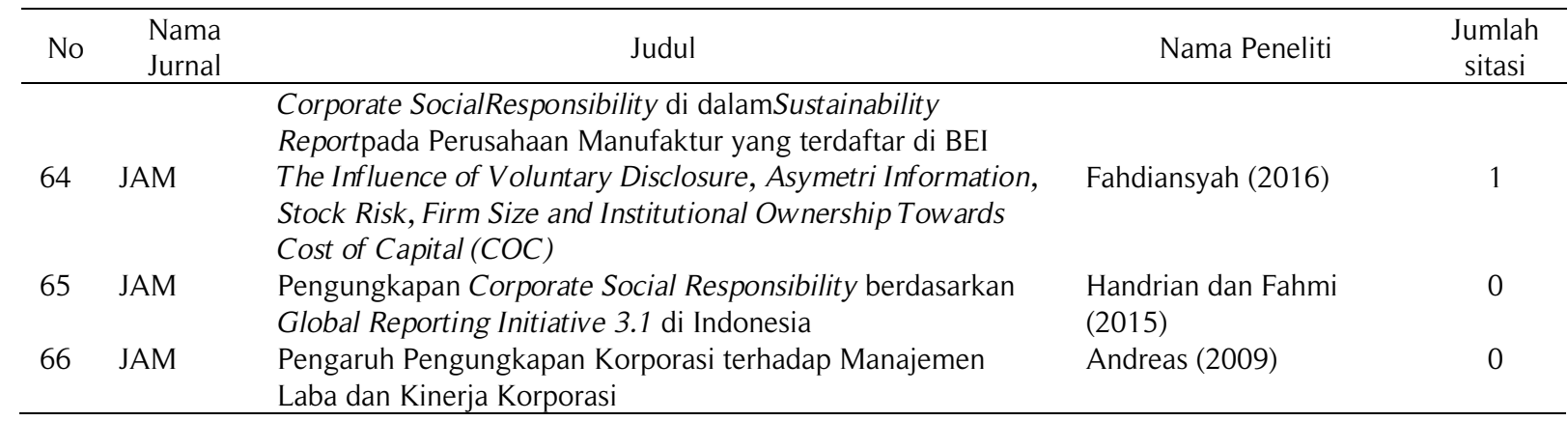

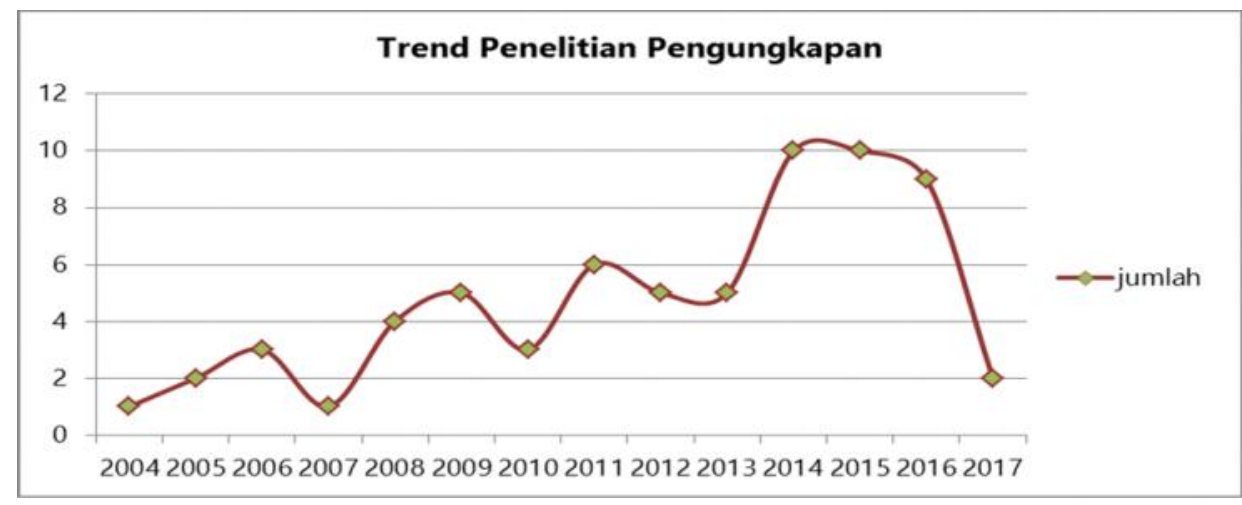

Gambar 1. Trend Penelitian Pengungkapan di Indonesia

Peneliti memilih periode 14 tahun antara tahun 2004 dan 2017 karena pada periode ini penelitian mengenai pengungkapan informasi keuangan di Indonesia mulai berkembang dan mengalami fluktuasi tiap tahunnya baik dari sisi pengungkapan wajib maupun pengungkapan sukarela proses seleksi menghasilkan 66 artikel. Pertimbangan tahun 2004 menjadi awal pengamatan adalah jurnal akreditasi yang memberikan ruang penelitian pengungkapan informasi perusahaan pertama kali terbit di Jurnal Akuntansi dan Auditing Indonesia tahun 2004 sebanyak 1 artikel. Sedangkan tahun 2017 sebagai akhir pengamatan adalah peneliti melihat bahwa di tahun 2017 penelitian mengenai pengungkapan informasi perusahaan masih dilakukan meskipun mengalami penurunan drastis yaitu hanya 2 artikel yang diterbitkan di Jurnal Akuntansi dan Keuangan Indonesia. Kami melakukan klasifikasi data bibliografi artikel yang terdiri atas nama jurnal, tahun publikasi, halaman, nama peneliti, afiliasi institusonal pada saat publikasi serta daftar referensi setiap artikel. Artikel yang tidak tersedia secara online tidak kami masukkan kedalam pemilihan jurnal.

Tabel 3. Deskripsi Sampel

\begin{tabular}{lcccccc}
\hline \multirow{2}{*}{ Nama Jurnal } & \multicolumn{2}{c}{2004 s/d 2017 } & \multicolumn{2}{c}{2004 s/d 2010 } & \multicolumn{2}{c}{ 2011 s/d 2017 } \\
\cline { 2 - 7 } & Jumlah & Persentase & Jumlah & Persentase & Jumlah & Persentase \\
\hline JAMAL & 11 & $17 \%$ & 3 & $14 \%$ & 8 & $18 \%$ \\
JAAI & 10 & $15 \%$ & 5 & $23 \%$ & 5 & $11 \%$ \\
JDM & 3 & $5 \%$ & 0 & $0 \%$ & 3 & $7 \%$ \\
JSB & 3 & $5 \%$ & 0 & $0 \%$ & 3 & $7 \%$ \\
JAK & 7 & $11 \%$ & 2 & $9 \%$ & 5 & $11 \%$ \\
JKP & 5 & $8 \%$ & 0 & $0 \%$ & 5 & $11 \%$ \\
JAKI & 18 & $27 \%$ & 7 & $32 \%$ & 11 & $25 \%$ \\
JAM & 4 & $6 \%$ & 1 & $5 \%$ & 3 & $7 \%$ \\
GMIJB & 3 & $5 \%$ & 3 & $14 \%$ & 0 & $0 \%$ \\
IRJBS & 1 & $2 \%$ & 0 & $0 \%$ & 1 & $2 \%$ \\
JMB & 1 & $2 \%$ & 1 & $5 \%$ & 0 & 0 \\
Total & 66 & & 22 & & 44 & 0 \\
\hline
\end{tabular}


Pada tabel 3 menunjukkan sampel yang digunakan dalam penelitian ini sesuai periode pengamatan yakni 2004 sampai 2017, ada satu jurnal yang mendominasi penelitian mengenai pengungkapan informasi perusahaan yaitu JAKI sebesar 27\%, sementara JAMAL 17\%, JAAI 15\%, JKP 9\%, JAM $6 \%$ dan JDM, JSB dan Gadjah Mada International Journal of Business sebesar 5\% sementara Internasional Research Journal of Business Studie dan Jurnal Manajemen Bisnis sebesar $1 \%$ atau hanya ada satu artikel saja yang terkait dengan pengungkapan informasi perusahaan.

Berdasarkan Tabel 3, rata-rata perbandingan dua periode yaitu periode antara tahun 2004 sampai dengan 2010 dan periode 2 antara tahun 2011 sampai dengan 2017 juga menunjukkan bahwa terjadi peningkatan jumlah artikel mengenai pengungkapan informasi perusahaan yang dipublikasikan dalam dekade terakhir yaitu dari 22 artikel menjadi 44 artikel atau hampir $70 \%$ peningkatannya. Peningkatan tersebut dipengaruhi oleh peningkatan jumlah penelitian dihampir semua jurnal.

\section{Pembahasan}

\section{Klasifikasi Artikel}

Pada artikel ini peneliti mengelompokkan setiap artikel pada dua klasifikasi yaitu topik dan metode penelitian dengan mengacu pada penelitian sebelumnya (Hesford et al., 2007).

\section{Klasifikasi berdasarkan Topik Pembahasan}

Pengklasifikasian artikel tentang pengungkapan informasi perusahaan berdasarkan pada topik penelitian dibedakan menjadi 2 yaitu anteseden (faktor-faktor yang memotivasi terjadinya pengungkapan informasi perusahaan).

Tabel 4. Klasifikasi Artikel berdasarkan Topik

\begin{tabular}{lcccccc}
\hline \multirow{2}{*}{ Nama Jurnal } & \multicolumn{2}{c}{2004 s/d 2017 } & \multicolumn{2}{c}{ 2004 s/d 2010 } & \multicolumn{2}{c}{ 2011 s/d 2017 } \\
\cline { 2 - 6 } & Jumlah & Persentase & Jumlah & Persentase & Jumlah & Persentase \\
\hline Anteseden & 29 & 0,44 & 9 & 0,47 & 20 & 0,43 \\
Konsekuensi & 19 & 0,29 & 5 & 0,26 & 14 & 0,30 \\
Anteseden \& Konsekuensi & 1 & 0,02 & 0 & 0,00 & 1 & 0,02 \\
Lainnya & 17 & 0,26 & 5 & 0,26 & 12 & 0,26 \\
Total & 66 & & 19 & & 47 & \\
\hline
\end{tabular}

Tabel 4, menunjukkan klasifikasi artikel yang membahas tentang pengungkapan informasi perusahaan di Indonesia berdasarkan topik yang dibahas. Seperti yang dijelaskan sebelumnya bahwa topik yang dibahas diklasifikasikan menjadi empat. Dari tabel 4 dapat disimpulkan bahwa selama 14 tahun topik yang dibahas adalah anteseden dari pengungkapan informasi perusahaan atau sekitar 43 persen (29 artikel), sedangkan yang membahas mengenai konsekuensi dan lainnya (menggambarkan mengenai apa yang terjadi jika perusahaan mengungkapkan informasi perusahaan) adalah sekitar 28 persen (19 artikel) dan yang membahas kombinasi antara anteseden dan konsekuensi adalah sekitar 4 persen atau 3 artikel saja. Jika diperbandingkan antara periode 1 dan periode 2 telah terjadi peningkatan cukup signifikan pada topik anteseden sekitar lebih dari 50 persen (dari 12 artikel menjadi 17 artikel), sedangkan yang membahas tentang konsekuensi dan lainnya sekitar lebih dari 100 persen (dari 5 artikel menjadi 14 dan 12 artikel). Namun jika dilihat dari kombinasi antara anteseden dan konsekuensi terjadi kenaikan yang signifikan dari tidak ada penelitian menjadi ada 1 penelitian. 
Tabel 5. Klasifikasi Variabel Anteseden

\begin{tabular}{lccccc}
\hline \multicolumn{1}{c}{ Variabel Anteseden } & Jumlah & $\%$ & \multicolumn{3}{c}{ Pengaruh } \\
\cline { 5 - 6 } & & & + & - & Tidak Berpengaruh \\
\hline Ukuran Perusahaan & 16 & $21 \%$ & 9 & 1 & 6 \\
Umur Perusahaan & 4 & $5 \%$ & 1 & 1 & 2 \\
Tipe Industri & 4 & $5 \%$ & 3 & - & 1 \\
Kinerja Perusahaan & 1 & $1 \%$ & - & - & 7 \\
Rasio Keuangan & 15 & $20 \%$ & 6 & 2 & - \\
Persepsi Penyedia dan Pengguna & 1 & $1 \%$ & 1 & - & - \\
Good Corporate Governance & 1 & $1 \%$ & 1 & - & 5 \\
Struktur Kepemilikan & 13 & $17 \%$ & 6 & 2 & - \\
Dewan Komisaris & 11 & $14 \%$ & 4 & 2 & 1 \\
Komite Audit & 3 & $4 \%$ & 3 & - & - \\
Reputasi Kantor Akuntan Publik & 1 & $1 \%$ & 1 & - & - \\
Kualitas Audit & 3 & $4 \%$ & 2 & 1 & - \\
Ukuran Kantor Akuntan Publik & 1 & $1 \%$ & - & - & - \\
Price to Book Value & 1 & $1 \%$ & 1 & - & - \\
Asset Turnover & 1 & $1 \%$ & 1 & - & - \\
Gross Earning & 1 & $1 \%$ & 1 & - & - \\
Status Perusahaan & 1 & $1 \%$ & 1 & - & - \\
Starategi Perusahaan & 1 & $1 \%$ & 1 & - & - \\
Slack Resources & 1 & $1 \%$ & 1 & - & - \\
Profile Perusahaan & 2 & $3 \%$ & 2 & - & - \\
\hline
\end{tabular}

Tabel 5 menjelaskan secara detail mengenai variabel anteseden apa saja yang dibahas oleh peneliti. Secara keseluruhan, dari 29 artikel yang membahas tentang variabel anteseden variabel ukuran perusahaan yang paling dominan dibahas sekitar 21 persen, sedangkan variabel rasio keuangan dan struktur kepemilikan masing-masing sekitar 20 persen dan 17 persen. Untuk variabel dewan komisaris sebesar 14 persen sedangkan variabel umur dan tipe industri sebesar 5 persen, komite audit dan kualitas audit sebesar 4 persen serta variabel lainnya sebesar 1 persen. Jadi, kesimpulannya adalah para peneliti di Indonesia lebih banyak meneliti faktor ukuran perusahaan, rasio keuangan dan struktur kepemilikan yang memengaruhi praktik pengungkapan informasi perusahaan di Indonesia.

Tabel 6. Klasifikasi Variabel Konsekuensi

\begin{tabular}{|c|c|c|c|c|c|}
\hline \multirow[b]{2}{*}{ Faktor Konsekuensi } & \multirow[b]{2}{*}{ Jumlah } & \multirow[b]{2}{*}{ Persentase } & \multicolumn{3}{|c|}{ Pengaruh } \\
\hline & & & + & - & $\begin{array}{c}\text { Tidak } \\
\text { Berpengaruh }\end{array}$ \\
\hline Kinerja Keuangan/Kinerja Perusahaan/Kinerja Pasar & 5 & $23 \%$ & 1 & 1 & 3 \\
\hline Nilai Perusahaan & 3 & $14 \%$ & 3 & - & - \\
\hline Reputasi & 1 & $5 \%$ & 1 & - & - \\
\hline Penghindaran Pajak & 2 & $9 \%$ & 1 & 1 & - \\
\hline Manajemen Laba & 1 & $5 \%$ & - & - & 1 \\
\hline Pengambilan Keputusan Investor/Reaksi Investor & 1 & $5 \%$ & 1 & - & - \\
\hline Earning Response Coefficient & 2 & $9 \%$ & 1 & - & 1 \\
\hline Cost of Debt & 1 & $5 \%$ & - & - & 1 \\
\hline Imbal Hasil Saham/Return Saham & 2 & $9 \%$ & 1 & - & 1 \\
\hline Volume Perdagangan & 1 & $5 \%$ & - & - & 1 \\
\hline Pihak Berelasi & 1 & $5 \%$ & - & - & 1 \\
\hline Cost of Equity Capital (CEC) & 1 & $5 \%$ & - & - & 1 \\
\hline Harga Saham & 1 & $5 \%$ & 1 & - & - \\
\hline
\end{tabular}


Tabel 6 menunjukkan tentang variabel konsekuensi atau dampak dari pengungkapan informasi yang dibahas oleh peneliti. Dari 19 artikel yang membahas mengenai pengungkapan informasi perusahaan, dampak yang paling dominan dibahas adalah kinerja perusahaan sekitar 22 persen (5 artikel), sedangkan dampaknya terhadap nilai perusahaan dan penghindaran pajak sebanyak 3 artikel (15 persen), return saham dan earning response coefficient 2 artikel (9 persen) dan yang lainnya sekitar 4 persen.

Tabel 7. Klasifikasi Topik Lainnya

\begin{tabular}{lc}
\hline Topik Lainnya & Jumlah \\
\hline Penyusunan Indeks & 3 \\
IPO & 1 \\
Komparasi & 4 \\
Variabel Moderasi & 1 \\
Financial Distress & 1 \\
Pemaknaan & 1 \\
Variabel Intervening & 1 \\
Pengujian dan Penerapan & 4 \\
Organisasi Pengelola Zakat & 1 \\
\hline
\end{tabular}

Tabel 7 menunjukkan tentang topik lainnya yang dibahas peneliti. Topik lainnya ini biasanya peneliti mencoba untuk menganalisis praktik pengungkapan informasi perusahaan pada kondisi tertentu, atau mengonstruksi indikator pengungkapan bahkan peneliti mencoba membandingkan praktik pengungkapan antara negara A dan B atau antara perusahaan A dan B. Peneliti juga menggunakan variabel pengungkapan informasi sebagai variabel intervening dan moderating.

Dari 17 artikel yang membahas topik lainnya dari pembahasan pengungkapan informasi perusahaan yang paling dominan adalah pengujian dan penerapan serta komparasi yaitu masingmasing berjumlah 4 artikel, sedangkan untuk penyusunan indeks sebanyak 3 artikel. Terdapat artikel yang membahas mengenai keadaan dimana perusahaan melakukan pengungkapan informasi keuangan yaitu perusahaan yang melakukan IPO dan yang sedang mengalami finansial distress masing-masing sebanyak 1 artikel. Terdapat pula artikel yang melakukan pemaknaan kembali mengenai pengungkapan informasi perusahaan yaitu sebanyak 1 artikel, serta menjadikan pengungkapan sebagai variabel moderasi dan intervening masing-masing sebanyak 1 artikel.

\section{Klasifikasi berdasarkan Populasi Penelitian}

Tabel 8 menunjukkan populasi penelitian. Dari 66 artikel yang diteliti populasi yang paling dominan diteliti adalah perusahaan publik yang terdaftar di bursa efek Indonesia yaitu sebanyak 31 artikel, perusahaan non keuangan dan keuangan masing-masing sebanyak 5 artikel dan 2 artikel sedangkan pada perusahaan manufaktur sebanyak 6 artikel dan pada perbankan 4 artikel, perbankan syariah sebanyak 5 artikel adapula yang meneliti pada organisasi pengelola zakat sebanyak 2 artikel.

Tabel 8. Klasifikasi Populasi Penelitian

\begin{tabular}{|c|c|c|c|c|c|}
\hline No & Populasi & Jumlah & No & Populasi & Jumlah \\
\hline 1 & Perusahaan Manufaktur & 6 & 9 & Perusahaan Publik Indeks LQ-45 & 1 \\
\hline 2 & Perusahaan yang Listed di BEI & 31 & 10 & Perusahaan Jasa & 1 \\
\hline 3 & Perusahaan Perbankan & 4 & 11 & Perusahaan Keuangan & 2 \\
\hline 4 & Perusahaan Non Keuangan & 5 & 12 & Perusahaan Peserta Proper & 1 \\
\hline 5 & Perusahaan IPO & 1 & 13 & Perusahaan Rokok & 1 \\
\hline 6 & Perusahaan Telekomunikasi Asia Pasifik & 1 & 14 & Organisasi Pengelola Zakat & 2 \\
\hline 7 & Perusahaan Sektor Rill & 1 & 15 & Perusahaan di Malaysia & 1 \\
\hline 8 & Perusahaan Perbankan Syariah & 5 & 16 & $\begin{array}{l}\text { Perusahaan Terdaftar di Jakarta } \\
\text { Stock Exchange }\end{array}$ & 3 \\
\hline
\end{tabular}




\section{Klasifikasi Artikel berdasarkan Metode Penelitian}

Berdasarkan metode penelitian yang digunakan oleh para peneliti untuk meneliti praktik pengungkapan informasi perusahaan di Indonesia diklasifikasikan berdasarkan pada 3 metode penelitian yaitu metode analytical, metode literature review dan metode survey.

Tabel 9 menunjukkan klasifikasi artikel yang membahas pengungkapan informasi perusahaan di Indonesia berdasarkan metode penelitian yang digunakan. Metode penelitian yang dibahas diklasifikasikan menjadi tiga (analytical, survey dan literature review). Metode analytical adalah para peneliti menggunakan berbagai teknik analisis data baik regresi berganda, analisis deskriptif, content analysis dengan menggunakan berbagai alat misalnya SPSS, SEM, E-Views dan Amos untuk menguji hubungan antar variabel. Metode literature review adalah para peneliti melakukan perbandingan atau studi kasus mengenai laporan keuangan dan pengujian kembali indeks serta teori. Metode survey adalah peneliti melakukan penyebaran kuesioner dengan skala likert untuk mengetahui persepsi penyedia laporan keuangan dan pemaknaan laporan keuangan.

Dari Tabel 9 dapat disimpulkan bahwa selama 14 tahun metode penelitian yang banyak digunakan oleh peneliti di Indonesia adalah metode analytical yaitu sekitar 89 persen (59 artikel), sedangkan yang menggunakan metode literature review dan survey masing-masing sekitar 9 persen (6 artikel) dan 2 persen ( 1 artikel saja). Jika dilihat pada periode 1 masih didominasi oleh metode analytical yaitu sekitar 86 persen (18 artikel), literature review sekitar 9 persen ( 2 artikel saja) dan metode survey sekitar 5 persen atau hanya 1 artikel saja.

Sedangkan pada periode 2 telah terjadi peningkatan yang cukup signifikan pada metode analytical sekitar lebih dari 100 persen (dari 18 artikel menjadi 41 artikel), sedangkan metode literaturereview mengalami kenaikan juga dari 2 artikel menjadi 4 artikel. Namun demikian, telah terjadi penurunan dari jumlah artikel yang menggunakan metode survey pada periode 2 ini yaitu tidak ada lagi peneliti yang menggunakan metode ini. Jadi dapat disimpulkan bahwa metode penelitian yang paling dominan digunakan peneliti di Indonesia ketika meneliti praktik pengungkapan informasi perusahaan yaitu dengan metode analytical.

Tabel 9. Klasifikasi Artikel berdasarkan Metode Penelitian

\begin{tabular}{lcccccc}
\hline \multirow{2}{*}{ Nama Jurnal } & \multicolumn{2}{c}{$2004 \mathrm{~s} / \mathrm{d} 2017$} & \multicolumn{2}{c}{$2004 \mathrm{~s} / \mathrm{d} 2010$} & \multicolumn{2}{c}{$2011 \mathrm{~s} / \mathrm{d} 2017$} \\
\cline { 2 - 7 } & Jumlah & Persentase & Jumlah & Persentase & Jumlah & Persentase \\
\hline Analytical & 59 & 0,89 & 18 & 0,86 & 41 & 0,91 \\
Review & 6 & 0,09 & 2 & 0,09 & 4 & 0,09 \\
Survey & 1 & 0,02 & 1 & 0,05 & 0 & 0,00 \\
Total & 66 & & 21 & & 45 & \\
\hline
\end{tabular}

\section{Karakteristik Jurnal}

Pada bagian ini akan dijelaskan mengenai pengelompokan jurnal yang membahas tentang praktik pengungkapan informasi perusahaan yang dikelompokkan berdasarkan topik dan metode penelitian. Tabel 10 menunjukkan karakteristik jurnal dibandingkan dengan topik penelitian yang dibahas oleh peneliti di Indonesia. Untuk topik penelitian anteseden dari praktik pengungkapan informasi perusahaan pada jurnal JAMAL, JAAI, JDM, JAK, Siasat Bisnis, JAKI, JAM, GMIJBdan JKP masing-masing sekitar 7 persen, 18 persen, 4 persen, 14 persen, 11 persen, 32 persen, 4 persen, 4 persen dan 7 persen.

Sedangkan untuk topik penelitian konsekuensi dari praktik pengungkapan informasi perusahaan dan topik lainnya terjadi persamaan jumlah pada jurnal JAMAL, JAAI, JDM, JAK, JAKI, JAM,IRJBS dan JKP masing-masing sekitar 5 persen, 16 persen, 5 persen, 11 persen, 42 persen, 11 persen, 5 persen dan 
5 persen. Untuk topik penelitian anteseden dan konsekuensi dari praktik pengungkapan informasi perusahaan hanya pada 3 jurnal yaitu JAMAL dan JAK masing-masing 50 persen.

Tabel 10. Klasifikasi Jurnal berdasarkan Topik Penelitian

\begin{tabular}{|c|c|c|c|c|c|c|c|c|c|}
\hline \multirow[b]{2}{*}{ Nama Jurnal } & \multicolumn{8}{|c|}{ Topik } & \multirow[b]{2}{*}{ Tota } \\
\hline & Anteseden & $\%$ & Konsekuensi & $\%$ & $\begin{array}{l}\text { Anteseden \& } \\
\text { Konsekuensi }\end{array}$ & $\%$ & Lainnya & $\%$ & \\
\hline JAMAL & 2 & $7 \%$ & 1 & $5 \%$ & 1 & $50 \%$ & 7 & $41 \%$ & 11 \\
\hline JAAI & 5 & $18 \%$ & 3 & $16 \%$ & 0 & $0 \%$ & 2 & $12 \%$ & 10 \\
\hline JDM & 1 & $4 \%$ & 1 & $5 \%$ & 0 & $0 \%$ & 1 & $6 \%$ & 3 \\
\hline JSB & 3 & $11 \%$ & 0 & $0 \%$ & 0 & $0 \%$ & 0 & $0 \%$ & 3 \\
\hline JAK & 4 & $14 \%$ & 2 & $11 \%$ & 1 & $50 \%$ & 0 & $0 \%$ & 7 \\
\hline JKP & 2 & $7 \%$ & 1 & $5 \%$ & 0 & $0 \%$ & 2 & $12 \%$ & 5 \\
\hline JAKI & 9 & $32 \%$ & 8 & $42 \%$ & 0 & $0 \%$ & 1 & $6 \%$ & 18 \\
\hline JAM & 1 & $4 \%$ & 2 & $11 \%$ & 0 & $0 \%$ & 1 & $6 \%$ & 4 \\
\hline GMIJB & 1 & $4 \%$ & 0 & $0 \%$ & 0 & $0 \%$ & 2 & $12 \%$ & 3 \\
\hline IRJBS & 0 & $0 \%$ & 1 & $5 \%$ & 0 & $0 \%$ & 0 & $0 \%$ & 1 \\
\hline JMB & 0 & $0 \%$ & 0 & $0 \%$ & 0 & $0 \%$ & 1 & $6 \%$ & 1 \\
\hline Total & 28 & & 19 & & 2 & & 17 & & 66 \\
\hline
\end{tabular}

Tabel 11 menunjukkan karakteristik jurnal dibandingkan dengan metode penelitian yang digunakan oleh peneliti di Indonesia. Untuk metode penelitian analytical pada jurnal JAMAL, JAAI, JDM, JAK, Siasat Bisnis, JAKI, JAM, Internasional Research Journal of Business Studie, Gadjah Mada International Journal of Business, Jurnal manajemen bisnis dan JKP masing-masing sekitar 10 persen, 15 persen, 5 persen, 12 persen, 5 persen, 30 persen, 7 persen, 2 persen, 5 persen, 2 persen dan 8 persen. Jadi untuk metode analytical ini hampir merata di semua jurnal menggunakan metode ini, sedangkan metode literature review hanya ada 5 artikel yang kesemuanya diterbitkan di jurnal JAMAL. Untuk metode penelitian survey hanya ada di jurnal JAAI hanya 1 artikel (Sayidah, 2004).

Tabel 11. Klasifikasi Jurnal berdasarkan Metode Penelitian

\begin{tabular}{lcccccc}
\hline \multirow{2}{*}{ Nama Jurnal } & \multicolumn{7}{c}{ Metode Penelitian } \\
\cline { 2 - 7 } & Analytical & $\%$ & Review & $\%$ & Survey & $\%$ \\
\hline JAMAL & 6 & $10 \%$ & 5 & $100 \%$ & - & 0 \\
JAAI & 9 & $15 \%$ & - & 0 & 1 & $100 \%$ \\
JDM & 3 & $5 \%$ & - & 0 & - & 0 \\
JSB & 3 & $5 \%$ & - & 0 & - & 0 \\
JAK & 7 & $12 \%$ & - & 0 & - & 0 \\
JKP & 5 & $8 \%$ & - & 0 & - & 0 \\
JAKI & 18 & $30 \%$ & - & 0 & - & 0 \\
JAM & 4 & $7 \%$ & - & 0 & - & 0 \\
GMIJB & 3 & $5 \%$ & - & 0 & - & 0 \\
IRJBS & 1 & $2 \%$ & - & 0 & - & 0 \\
JMB & 1 & $2 \%$ & - & 0 & - & 0 \\
Total & 60 & & 5 & & 1 & \\
\hline
\end{tabular}

\section{Perbandingan Artikel dilihat dari Topik dan Metode Penelitian}

Tabel 12 menunjukkan karakteristik artikel berdasarkan Cross-tabulation antara topik dengan metode penelitian. Metode penelitian analytical yang paling banyak digunakan oleh peneliti untuk 
meneliti topik anteseden dari praktik pengungkapan informasi perusahaan sekitar 27 artikel, sedangkan untuk topik konsekuensi sekitar 19 artikel, topik anteseden dan konsekuensi 2 artikel dan topik lainnya sekitar 11 artikel. Dapat dilihat juga bahwa literature review dan metode survey kurang mendominasi penelitian mengenai praktik pengungkapan informasi perusahaan selain ketiga topik di atas yaitu 1 artikel dan 6 artikel. Jadi masih terbuka lebar bagi peneliti selanjutnya untuk lebih banyak mengembangkan metode penelitian literature review dan survey untuk meneliti praktik pengungkapan informasi perusahaan di Indonesia. Hal ini pula yang memotivasi peneliti untuk menulis artikel ini.

Tabel 12. Klasifikasi Artikel berdasarkan Perbandingan Topik dan Metode Penelitian

\begin{tabular}{lcccc}
\hline \multirow{2}{*}{ Nama Jurnal } & \multicolumn{4}{c}{ Topik } \\
\cline { 2 - 5 } & Anteseden & Konsekuensi & Anteseden \& Konsekuensi & Lainnya \\
\hline Analytical & 27 & 19 & 2 & 11 \\
Survey & 1 & 0 & 0 & 0 \\
Review & 0 & 0 & 0 & 6 \\
Total & 28 & 19 & 2 & 17 \\
\hline
\end{tabular}

\section{Karakteristik Model Pengungkapan}

Tabel 13 menjelaskan karakteristik model praktik pengungkapan informasi perusahaan yang digunakan oleh peneliti di Indonesia. Model pengungkapan yang paling banyak diteliti adalah pengungkapan Corporate Social Responsibility, pengungkapan wajib dan sukarela, pengungkapan Intellectual Capital yaitu masing-masing sekitar 33 persen (22 artikel), 14 persen ( 9 artikel), dan 12 persen ( 8 artikel).

Tabel 13. Model Pengungkapan Informasi Perusahaan

\begin{tabular}{lcc}
\hline Nama Jurnal & Jumlah & Persentase \\
\hline Corporate Governance & 3 & 0,05 \\
Intellectual Capital & 8 & 0,12 \\
Corporate Social Responsibility & 22 & 0,33 \\
Islamic Corporate Social Responsibility & 1 & 0,02 \\
Proforma & 2 & 0,03 \\
Research \& Development & 1 & 0,02 \\
Sustainability & 1 & 0,02 \\
Wajib Dan Sukarela & 9 & 0,14 \\
Internet & 3 & 0,05 \\
Enterprise Management & 1 & 0,02 \\
Kompensasi Manajemen & 1 & 0,02 \\
Luas Pengungkapan & 3 & 0,05 \\
Lainnya & 11 & 0,17 \\
\hline
\end{tabular}

\section{Perbandingandengan Penelitian Terdahulu}

Kami menemukan beberapa artikel internasional yang membahas mengenai perkembangan penelitian pengungkapan informasi keuangan namun artikel tersebut telah usang atau lama dan hanya berfokus pada suatu bidang pengungkapan tertentu bahkan tidak ada yang membahas perkembangan penelitian pengungkapan informasi secara lebih luas dan mendalam. Sehingga kami berinisiatif menulis artikel ini guna memberikan pengetahuan baru mengenai perkembangan penelitian terkait pengungkapan informasi sehingga dapat dijadikan referensi bagi penelitian selanjutnya untuk mengembangkan topik yang masih sedikit diteliti. 
Kami menemukan artikel yang hampir mirip dengan penelitian kami namun artikel tersebut hanya berfokus pada pengungkapan lingkungan. Artikel tersebut ditulis oleh Berthelot, Cormier dan Magnan (2002) dengan judul Enviromental Disclosure Research: Review and Synthetics. Tujuan dari penelitian tersebut mengkaji penelitian pengungkapan lingkungan. Penelitian tersebut mengambil sampel selama 10 tahun terakhir yaitu tahun 1990-2000 dan menemukan 21 artikel. Penelitian tersebut hanya berfokus pada perkembangan penelitian pengungkapan berbasis lingkungan dengan mengklasifikasikan artikel berdasarkan pada nama pengarang, tahun terbit, fokus penelitian, dan hasil penelitian. Penelitian tersebut juga membagi topik bahasan menjadi voluntary enviromental disclosure dan external enviromental disclosure.

Artikel yang kami temukan selanjutnya hanya berfokus pada masalah regulasi pengungkapan informasi perusahaan yang ditulis oleh Leuz dan Wysocki (2008) yang berjudul Economic Consequences of Financial Reporting and Disclosure Regulation: A Review and Suggestions for Future Research. Artikel lainnya juga hanya berfokus pada pengungkapan lingkungan di Afrika Selatan yang ditulis oleh Antonites dan Villiers (2003) yang berjudul Trends in South African Corporate Enviromental Reporting: A Research Note.

\section{Saran Penelitian Selanjutnya}

Tabel 13 menunjukkan bahwa masih terdapat topik tentang pengungkapan informasi perusahaan yang masih jarang diteliti padahal topik tersebut sangat menarik dan populer di tengah-tengah dunia bisnis. Penelitian selanjutnya diharapkan dapat menggunakan artikel ini untuk melihat penelitian mana yang masih jarang dan sudah banyak diteliti dan kemudian meneliti topik-topik yang masih jarang diteliti seperti islamic corporate social responsibility mengingat saat ini sedang berkembang entitas syariah dan islamic corporate social responsibility sedang menjadi tema yang banyak dibicarakan tidak hanya di negara-negara yang penduduknya mayoritas muslim, tetapi telah menjadi objek utama pada penelitian di berbagai negara termasuk negara yang penduduknya menganut kepercayaan lain dan tidak menjalankan hukum syariah sebagai dasar etika dalam bisnis. Selain itu, islamic corporate social responsibility menjadi jawaban dari aktivitas tanggungjawab sosial perusahaan saat ini yang kurang menekankan nilai sosial dan lebih menekankan pada nilai materialistik ketimbang nilai sosial dan ketuhanan, meskipun setiap manusia memiliki hak dalam menentukan pilihan dan tujuan bisnisnya (Arifin dan Wardani, 2016), sehingga topik mengenai islamic corporate social responsibility sangat menarik diteliti baik dari segi anteseden, konsekuensi, dan lainnya misalnya mengkonstruksi indeks ICSR atau melakukan komparasi.

Sustainability Reporting merupakan salah satu topik yang sangat menarik untuk diteliti mengingat pengungkapan ini sangat berpengaruh bagi investor dalam pengambilan keputusan investasi guna melihat keberlangsungan usaha dimasa yang akan datang serta melihat komitmen dan kontribusi perusahaan terhadap pengembangan tingkat ekonomi yang berkelanjutan untuk meningkatkan kualitas hidup masyarakat di sekitar wilayah perusahaan. Selain itu di Indonesia, publikasi sustainability report sudah mulai menjadi tren, salah satunya didorong oleh adanya pemberian penghargaan tahunan atas sustainability report yang diinisiasi oleh lembaga National Center for Sustainability Reporting (NCSR). Selain itu, menguatnya tuntutan stakeholders mendorong perusahaan untuk memberikan informasi yang transparan, akuntabel, dan praktik tata kelola perusahaan yang baik.

Namun, Penelitian terdahulu yang dilakukan tekait sustainabilityreport sebagian besar hanya berfokus untuk melihat dampak sustainability report terhadap indikator kinerja keuangan (Tarigan dan Semuel, 2014), sehingga penelitian selanjutnya diharapkan dapat melihat dari sisi anteseden maupun melakukan konstruksi indeks atau komparasi. Walaupun sudah banyak yang meneliti mengenai sustainability reporting ternyata hanya 1 artikel yang diterbitkan di jurnal terakreditasi nasional, sehingga hal ini menjadi peluang yang bagus bagi para peneliti yang menginginkan artikelnya dapat terbit di jurnal terakreditasi nasional. 
Pengungkapan biaya research and development merupakan salah satu pengungkapan yang menarik untuk diteliti sebab pengungkapan biaya riset dan pengembangan penting bagi investor untuk melihat sejauh mana inovasi yang dilakukan oleh entitas bisnis guna pengambilan keputusan karena pengungkapan ini berkaitan dengan proyeksi atau perkiraan kondisi keuangan entitas bisnis dimasa yang akan datang, akantetapi selama 14 tahun belum ada yang meneliti lagi mengenai pengungkapan biaya riset dan pengembangan baik dari segi anteseden, konsekuensi maupun topik lain misalnya mengonstruksi ulang model dan teori pengungkapannya atau komparasi praktik pengungkapan di beberapa negara. Hal tersebut menjadi peluang bagi para peneliti untuk melakukan penelitian di bidang pengungkapan riset dan pengembangan.

\section{Simpulan}

Dalam studi ini, peneliti menganalisis 66 artikel yang membahas tentang praktik pengungkapan informasi perusahaan dan diterbitkan 11 jurnal akreditasi di Indonesia yang diklasifikasikan berdasarkan topik, metode, dan data kutipan pada 11 jurnal dari 2004 hingga tahun 2017. Mayoritas artikel hasil penelitian tentang Pengungkapan Informasi Perusahaan di Indonesia rata-rata diterbitkan di 3 Jurnal yaitu Jurnal Akuntansi \& Keuangan Indonesia (JAKI) Universitas Indonesia, Jurnal Akuntansi dan Auditing Indonesia (JAAI) Universitas Islam Indonesia dan Jurnal Multiparadigma (JAMAL) Universitas Brawijaya. Topik yang banyak dibahas dari artikel praktik pengungkapan informasi perusahaan yang diterbitkan di 11 jurnal adalah topik anteseden dari praktik pengungkapan informasi perusahaan atau sekitar 43\% (29 artikel), sehingga penelitian selanjutnya dapat meneliti lebih luas lagi mengenai topik konsekuensi ataupun topik lainnya misalnya pengujian kembali teori dan indeks pengungkapan atau melakukan studi komparasi antar negara atau perusahaan.

Selama 14 tahun metode penelitian yang banyak digunakan oleh peneliti di Indonesia untuk meneliti praktik pengungkapan informasi perusahaan adalah metode analytical yaitu sekitar 89\% (59 artikel) sedangkan $11 \%$ lainnya dengan metode lain seperti literaturereview dan survey sehingga penelitian selanjutnya dapat menggunakan metode yang masih jarang digunakan yaitu survey dan literature review untuk meneliti praktik pengungkapan informasi perusahaan di Indonesia. Model yang banyak dipakai adalah model pengungkapan corporate social responsibility sekitar 33 persen atau 22 artikel dengan alasan bahwa pengungkapan ini berkaitan dengan tanggungjawab perusahaan kepada banyak orang dan banyak menimbulkan konflik ditegah masyarakat. Selain itu, pengungkapan corporate social responsibility menjadi sinyal yang diberikan pihak manajemen kepada seluruh stakeholder termasuk calon investor mengenai prospek perusahaan di masa depan serta menunjukkan nilai lebih yang dimiliki oleh perusahaan atas kepeduliannya terhadap dampak ekonomi, sosial dan lingkungan yang timbul dari aktivitas perusahaan.

\section{Daftar Pustaka}

Adhariani, D. (2005). Tingkat Keluasan Pengungkapan Sukarela dalam Laporan Tahunan dan Hubungannya dengan Current Earnings Response Coefficient. Jurnal Akuntansi dan Keuangan Indonesia, 2(1), 24-57

Adiono, C. L., \& Sholihin, M. (2014). Analisis Pengungkapan Tata Kelola Bank Syariah di Indonesia. Jurnal Keuangan dan Perbankan, 18(2), 268-277

Akmyga, S. F., \& Mita, A. F. (2015). Pengaruh Struktur Corporate Governance dan Kualitas Audit terhadap Luas Pengungkapan Kompensasi Manajemen Kunci di Laporan Keuangan. Jurnal Akuntansi dan Keuangan Indonesia,12(1), 19-36 
Akhtaruddin, M., Hossain, M. A., Hossain, M., \& Yao, L. (2009). Corporate Governance and Voluntary Disclosure in Corporate Annual Reports of Malaysian Listed Firms. The Journal of Applied Management Accounting Research, 7(1), 1-20

Ali, I. M. A. (2012). Memaknai Disclosure Laporan Sumber dan Penggunaan Dana Kebajikan (Qardhul Hasan) Bank Syariah. Jurnal Akuntansi Multiparadigma, 3(2), 185-207

Alrazi, B., Sulaiman, M., \& Ahmad, N. (2009). A Longitudinal Examination of Environmental Reporting Practices in Malaysia. Gadjah Mada International Journal of Business, 11(1), 3772

Andreas. (2009). Pengaruh Pengungkapan Korporasi terhadap Manajemen Laba dan Kinerja Korporasi. Jurnal Aplikasi Manajemen, 7(4),897-903

Anggraeni, D. Y. (2015). Pengungkapan Emisi Gas Rumah Kaca, Kinerja Lingkungan, dan Nilai Perusahaan (Greenhouse Gas Emission Disclosure, Environmental Performance, and Firm Value). Jurnal Akuntansi dan Keuangan Indonesia, 12(2), 188-209

Anggraeni, D. Y., \& Djakman, C. D. (2017). Slack Resources, Feminisme Dewan, dan Kualitas Pengungkapan Tanggung Jawab Sosial Perusahaan. Jurnal Akuntansi dan Keuangan Indonesia, 14(1), 94-118

Antonites, E., \& Villiers, CJ de. (2003). Trends in South African Corporate Enviromental Reporting: A Research Note. Meditari Accountancy Research, 11, 1-10

Arifah, D. A. (2012). Pengaruh Mekanisme Corporate Governance terhadap Pengungkapan Intellectual Capital: pada Perusahaan IC Intensive. Jurnal Akuntansi dan Keuangan Indonesia, 9(2), 189-211

Arifin, J., \& Wardani, E. A. (2016). Islamic Corporate Social Responsibility Disclosure, Reputasi, dan Kinerja Keuangan: Studi pada Bank Syariah di Indonesia. Jurnal Akuntansi dan Auditing Indonesia, 20(1), 37-46

Awuy, V. P., Sayekti, Y., \& Purnamawati, I. (2016). Pengaruh Pengungkapan Corporate Social Responsibility (CSR) terhadap Earning Response Coefficient (ERC) (suatu Studi Empiris pada Perusahaan Pertambangan yang terdaftar di Bursa Efek Indonesia pada Tahun 20102013). Jurnal Akuntansi dan Keuangan, 18(1), 15-26

Belkaoui, A., \& Karpik, P.G. (1989). Determinant of the Corporate Desicion to Disclosure Social Information. Accounting, Auditing, and Accountability Journal, 2(1), 36-51.

Berthelot, S., Cormier, D., \& Magnan, M. (2002). Enviromental Disclosure Research: Review and Synthesis. CRG's Working Paper

Cahyaningsih., \& Martina, V. Y (2011). Pengaruh Mekanisme Corporate Governance dan Karakteristik Perusahaan terhadap Pengungkapan Tanggungjawab Sosial. Jurnal Siasat Bisnis, 15(2), 171-186

Devi, S., Budiasih, I. G. N., \& Badera, I. D. N. (2017). Pengaruh Pengungkapan Enterprise Risk Management dan Pengungkapan Intellectual Capital terhadap Nilai Perusahaan (The Effect of Enterprise Risk Management Disclosure and Intellectual Capital Disclosure on Firm Value). Jurnal Akuntansi dan Keuangan Indonesia, 14(1), 20-45

Eng, L. L., \& Mak, Y. T. (2003). Corporate Governance and Voluntary Disclosure. Journal of Accounting and Public Policy, 22(4), 325-245 
Fahdiansyah, R. (2016). The Influence of Voluntary Disclosure, Asymetri Information, Stock Risk, Firm Size and Institutional Ownership Towards Cost of Capital (COC). Jurnal Aplikasi Manajemen, 14(2), 387-397

Faizal, R. P., \& Probohudono, A. N. (2013). Determinan Voluntary Nonfinancial Disclosure pada Perusahaan di Indonesia. Jurnal Akuntansi dan Auditing Indonesia, 17(2), 87-101

Frendy., \& Kusuma, I. W. (2011). The Impact of Financial, Non-Financial, and Corporate Governance Attributes onThe Practice of Global Reporting Initiative (GRI)Based Environmental Disclosure. Gadjah Mada International Journal of Business, 13(2), 143-159

Handrian, I., \& Fahmi, I. (2015). Pengungkapan Corporate Social Responsibility berdasarkan Global Reporting Initiative 3.1 di Indonesia. Jurnal Aplikasi Manajemen, 14(1), 98-103

Hesford, J. W., Lee, S. H., Van der Stede, W. A., \& Young, S.M. (2007). Management Accounting: A BibliographicStudy. Handbook of Management Accounting Research. Elsevier Ltd. All, 16-39.

Hidayah, E. (2008). Pengaruh Kualitas Pengungkapan Informasi terhadap Hubungan antara Penerapan Corporate Governance dengan Kinerja Perusahaan di Bursa Efek Jakarta. Jurnal Akuntansi dan Auditing Indonesia, 12(1), 53-64

Ho, S. S. M., \& Wong, K. S. (2001). A Study of Corporate Disclosure Practices and Effectiveness in Hong Kong. Journal of International Financial Management and Accounting,12(1), 75-101

Ibrahim, M., Solikahan, E. Z., \& Widyatama, A. (2015). Karakteristik Perusahaan, Luas Pengungkapan Corporate Social Responsibility dan Nilai Perusahaan. Jurnal Akuntansi Multiparadigma, 6(1), 99-106

Irwhantoko., \& Basuki. (2016). Carbon Emission Disclosure: Studi pada Perusahaan Manufaktur di Indonesia. Jurnal Akuntansi dan Keuangan, 18(2), 92-104

Junaedi, D. (2005). Dampak Tingkat Pengungkapan Informasi Perusahaan terhadap Volume Perdagangan dan Return Saham (Penelitian Empiris Terhadap Perusahaan-Perusahaan yang tercatat di Bursa Efek Jakarta). Jurnal Akuntansi dan Keuangan Indonesia, 2(2), 1-28

Juniarti., \& Sentosa, A. A. (2009). Pengaruh Good Corporate Governance, Voluntary Disclosure terhadap Biaya Hutang. Jurnal Akuntansi dan Keuangan, 11(2), 88-100

Kesumajuda, F. A. (2006). Electronic Disclosure pada Perusahaan Telekomunikasi Asia Pasifik di New York Stock Exchange. Jurnal Akuntansi dan Keuangan Indonesia, 3(2), 213-238

Kurnianto, S., Sutrisno., \& Saraswati, E. (2014). Luas Pengungkapan dan Dampak terhadap Asimetri Informasi Perusahaan Sektor Keuangan. Jurnal Akuntansi Multiparadigma, 7(1), 142-155

Leuz, C., \& Wysocki, P. (2008). Economic Consequences of Financial Reporting and Disclosure Regulation: A Review and Suggestions for Future Research.

Lindawati, A. S. L., \& Puspita, M. E. (2015). Corporate Social Responsibility: Implikasi Stakeholder dan Legitimacy Gap dalam Peningkatan Kinerja Perusahaan. Jurnal Akuntansi Multiparadigma, 6(1), 157-174

Meutia, I. (2010). The Concept of Social Responsibility Disclosures for Islamic Banks Based on Shari'ah Enterprise Theory. Jurnal Akuntansi Multiparadigma, 1(3), 361-374

Murwaningsari. (2014). Kepemilikan Institusional dan Kualitas Audit terhadap Pengungkapan Informasi dan Future Earnings Response Coefficient. Jurnal Keuangan dan Perbankan, 18(2), 161-171 
Nasution, R. M., \& Adhariani, D. (2016). Simbolis atau Substantif? Analisis Praktik Pelaporan CSR dan Kualitas Pengungkapan. Jurnal Akuntansi dan Keuangan Indonesia, 13(1), 23-51

Nugraheni, P. (2011). Voluntary Disclosure in Indonesia: Comparison of Shariah and Non Shariah Compliant Companies. Jurnal Akuntansi dan Auditing Indonesia, 15(1), 53-64

Nur DP, E., \& Susilowati, E. (2015). Perbandingan Tingkat dan Ruang Pengungkapan Pelaporan Keuangan Basis Internet terhadap Harga Saham. Jurnal Keuangan dan Perbankan, 19(2), 252-262

Nuryaman. (2009). Pengaruh Konsentrasi Kepemilikan, Ukuran Perusahaan dan Mekanisme Corporate Governance terhadap Pengungkapan Sukarela. Jurnal Akuntansi dan Keuangan Indonesia, 6(1), 89-116

Nussy, T. M. (2014). Pengungkapan Tanggungjawab Sosial Perbankan di Indonesia. Jurnal Keuangan dan Perbankan,18(2), 329-334

Oktavia., \& Martani, D. (2013). Tingkat Pengungkapan dan Penggunaan Derivatif Keuangan dalam Aktivitas Penghindaran Pajak. Jurnal Akuntansi dan Keuangan Indonesia, 10(2), 129-146

Oktaviani, I. H., \& Martani, D. (2006). Analisis Pengungkapan Laporan Keuangan Perusahaan Pembiayaan. Jurnal Akuntansi dan Keuangan Indonesia, 3(2), 239-260

Puspitasari, Y., \& Habiburrochman. (2013). Penerapan PSAK No.109 atas Pengungkapan Wajib dan Sukarela. Jurnal Akuntansi Multiparadigma, 4(3), 479-494

Rahman, A., \& Widyasari, K. N. (2008). The Analysis of Company Characteristic Influence Toward CSR Disclosure: Empirical Evidence of Manufacturing Companies Listed in JSX. Jurnal Akuntansi dan Auditing Indonesia, 12(1), 25-35

Ratmono, Dwi., Purwanto, A., \& Cahyonowati, N. (2014). Hubungan Tingkat Pengungkapan dan Kinerja Corporate Social Responsibility serta Manajemen Laba: Pengujian Teori Ekonomi dan Sosio-Politis. Jurnal Akuntansi dan Keuangan, 16(2), 63-73

Restuningdiah, N. (2011). Perataan Laba terhadap Reaksi Pasar dengan Mekanisme GCG dan CSRDisclosure. Jurnal Manajemen Bisnis, 3(3), 241-260

Restuti, M. D., \& Nathaniel, C. (2012). Pengaruh Pengungkapan Corporate Social Responsibility terhadap Earning Response Coefficient. Jurnal Dinamika Manajemen, 3(1), 40-48

Riantani, S., \& Nurzamzam, H. (2015). Analisis Company Size, Financial Leverage dan Profitabilitas serta Pengaruhnya terhadap Pengungkapan CSR. Jurnal Dinamika Manajemen, 6(2), 203213

Rini. (2016). Penerapan Internet Financial Reporting untuk Meningkatkan Akuntabilitas Organisasi Pengelola Zakat. Jurnal Akuntansi Multiparadigma, 7(2), 288-306

Rura, Y. (2010). Pengungkapan Pro Forma, Mendukung atau Menyesatkan Investor?. Jurnal Akuntansi Multiparadigma, 1(3), 375-392

Rura, Y., Subroto, B., Sudarman, M., \& Rosidi. (2011). Pengungkapan Pro Forma dan Keputusan Investor: Uji Empiris Teori Signal dan Teori Pasar Efisien di Bursa Efek Indonesia (BEI). Jurnal Akuntansi Multiparadigma, 2(2), 186-368

Santoso, S. (2012). Pengaruh Modal Intelektual Kapital dan Pegungkapannya terhadap Kinerja Perusahaan. Jurnal Akuntansi dan Keuangan, 14(1), 16-31 
Sari, D., \& Tjen, C. (2016). Corporate Social Responsibility Disclosure, Environmental Performance, and Tax Aggressiveness. Internasional Research Journal of Business Studie, 9(2), 93-104

Sari, R. S., Sutrisno., \& Sukoharsono, E. G. (2013). Pengaruh Kepemilikan Institusional, Komposisi Dewan Komisaris, Kinerja Perusahaan terhadap Luas Pengungkapan Corporate SocialResponsibility di dalam Sustainability Report pada Perusahaan Manufaktur yang Terdaftar di BEI. Jurnal Aplikasi Manajemen, 11(3), 481-491

Sayidah, N. (2004). Persepsi Penyedia dan Pemakai Laporan Keuangan terhadap Pengungkapan Biaya Riset dan Pengembangan. Jurnal Akuntansi dan Auditing Indonesia, 8(1), 81-98

Shella., \& Wedari, L. K. (2016). Intellectual Capital dan Intellectual Capital Disclosure terhadap MarketPerformance pada Perusahaan Publik Indeks LQ-45. Jurnal Akuntansi dan Auditing Indonesia, 20(1), 27-36

Solikhah, B., \& Winarsih, A. M. (2016). Pengaruh Liputan Media, Kepekaan Industri, dan Struktur Tata Kelola Perusahaanterhadap Kualitas Pengungkapan Lingkungan. Jurnal Akuntansi dan Keuangan Indonesia, 13(1), 1-22

Suhardjanto, D., \& Wardhani, M. (2010). Praktik Intellectual Capital Disclosure Perusahaan yang terdaftar di Bursa Efek Indonesia. Jurnal Akuntansi dan Auditing Indonesia, 14(1), 71-85

Supriyono, E., \& Suhardjanto, D. (2013). Praktik Pengungkapan Sosial: Studi Komparatif di Asia Tenggara. Jurnal Siasat Bisnis, 17(2), 187-207

Surifah. (2011). Arranging the Index Of Corporate Governance. Jurnal Dinamika Manajemen, 2(1), 1-16

Suripto, Bambang. (2014). Determinan Pengungkapan Informasi Atribusi dan Dampaknya terhadap Persistensi Laba. Jurnal Akuntansi dan Keuangan Indonesia, 11(1), 78-98

Susi. (2009). The Occurrence of Environmental Disclosures in the Annual Reports. Jurnal Akuntansi dan Auditing Indonesia,13(1), 29-42

Tarigan, J., \& Semuel, H. (2014). Pengungkapan Sustainability Report dan Kinerja Keuangan. Jurnal Akuntansi dan Keuangan,16(2), 88-101

Ulum, I. (2015). Intellectual Capital Disclosure: Suatu Analisis dengan Four Way Numerical Coding System. Jurnal Akuntansi dan Auditing Indonesia, 19(1), 39-50

Ulum, I., Ghozali, I., \& Agus. (2014). Konstruksi Model Pengukuran Kinerja dan Kerangka Kerja Pengungkapan Modal Intelektual. Jurnal Akuntansi Multiparadigma, 5(3), 345-510

Utama, C. (2015). Penentuan Besaran Transaksi Pihak Berelasi: Tata Kelola, Tingkat Pengungkapan dan Struktur Kepemilikan. Jurnal Akuntansi dan Keuangan Indonesia, 12(1), 37-54

Uzliawati, L. (2015). Dewan komisaris dan Intellectual Capital Disclosure pada Perbankan di Indonesia. Jurnal Keuangan dan Perbankan, 19(2), 226-234

Wardani, Rr. P. (2012). Faktor-Faktor yang Mempengaruhi Luas Pengungkapan Sukarela. Jurnal Akuntansi dan Keuangan, 14(1), 1-15

Widarjo, W. (2011). Pengaruh Modal Intelektual dan Pengungkapan Modal Intelektual pada Nilai Perusahaan yang Melakukan Initial Public Offering. Jurnal Akuntansi dan Keuangan Indonesia, 8(2), 157-170

Widyadmono, V. M. (2014). The Impact of Type of Industry, Company Size and Leverage on The Disclosure of Corporate Social Responsibility. Jurnal Siasat Bisnis, 18(1), 118-132 
Wijantini. (2006). Voluntary Disclosure in the Annual Reports of Financially Distressed Companies in Indonesia. Gadjah Mada International Journal of Business, 8(3), 343-365

Wondabio, L. S. (2007). Pengungkapan Non Financial Measures: Penilaian Value Relevance bagi Investor dan Pengaruhnya terhadap Cost Of Equity dan Performance bagi Perusahaan Publik. Jurnal Akuntansi dan Keuangan Indonesia, 4(1), 47-76

Wulandari, P. P., \& Atmini, S. (2012). Pengaruh Tingkat Pengungkapan Wajib dan Pengungkapan Sukarela terhadap Biaya Modal Ekuitas. Jurnal Akuntansi Multiparadigma, 3(3), 334-501

Yuen, C., Liu, M., Zhang, X., \& Lu, C. (2009). A Case Study of Voluntary in Medium-Size Companies: Exploring the Effects of Ownership and Governance Systems. Journal of Management,26(5): 947-976

Yuliana, R., Purnomosidhi, B., \& Sukoharsono, E. G. (2008). Pengaruh Karakteristik Perusahaan terhadap Pengungkapan Corporate Social Responsibility dan Dampaknya terhadap Reaksi Investor. Jurnal Akuntansi dan Keuangan Indonesia, 5(2), 245-276 